\title{
RED-ON-GRANITE ROCK PAINTING IN THE SIERRA DE SAN BORJA, BAJA CALIFORNIA
}

\author{
By \\ Harry Crosby*
}

\begin{abstract}
New discoveries in Baja California, north of the 28th parallel contradict an old tradition, and push the boundary of the Great Mural paintings further north than had been previously suggested. The new area not only displays works akin in size and subject matter to their more southern counterparts, but also shows some changes in choice of surfaces, paint colors, and stylistic conventions. Seven sites are reported; many others are predicted.
\end{abstract}

\section{RESUMEN}

Nuevos descubrimientos en Baja California, al norte del paralelo 28, contradicen una tradición anterior, y ubican la frontera de las Grandes' Pinturas Murales más al norte de lo que previamente se sugería. La nueva área no solamente exhibe obras parecidas en su tamafio y contenido a sus semejantes que se encuentran más al sur, sino demuestra algunos cambios en la elección de superficies, colores de pintura y reglas convencionales estilísticas. Se mencionan siete sitios y muchos más se pronostican.

\section{BACKGROUND}

The poorly-studied and little-known prehistoric people of Baja California created at least one potentially enduring monument. They left an almost unprecedented production of rock art, on as grandiose a scale as that of modern muralists in Mexico. The huge naturalistic paintings of the central peninsula have attracted world-wide attention almost from the time of their discovery by Europeans. Various Mission-Period (c. 1700-1800) accounts of them were circulated as far as Europe. A French visitor, the naturalist Leon Diguet, reported numerous finds in continental publications of his time (1895-1912). Erle Stanley Gardner rediscovered the phenomenon for

* Independent researcher. 
the lay public in the early 1960 's, and various others have added piecemeal accounts both before and after Gardner's time. This author is engaged in a project which thus far has involved eleven months in the field, and has resulted in the mapping and photographing of over 150 sites between Bahía de los Ángeles, on the north, and La Purísima, on the south. Over 100 of these were previously unrecorded. The author's purpose is to sample works throughout the range of the great murals and to determine the boundaries of this general style.

This brief interim paper anticipates a larger work, and reports what appears to be a rather large addition to the great mural area.

\section{GREAT MURALS IN THE SIERRA DE SAN BORJA}

It has been customary to cite the 28th parallel of $\mathrm{N}$. latitude as the northern boundary of the unique large-scale naturalistic rock paintings in Baja California. Such references can be found from at least as early as Clavijero's second-hand report in 1789 (Clavijero, 1937:85), to as recently as Campbell Grant's (1974:82) summary derived from various sources.

Despite the assurance of such reports, I have, for several years, heard conflicting stories from people who have known the remote interior of the Sierra de San Borja, a range of mountains which has its southern end some 25 kilometers north of the 28 th parallel, and extends another 60 kilometers north.

It must be added, parenthetically, that previously-published reports of paintings in this sierra seem to stem from an error in a report by Dr. Clement Meighan (Meighan, 1966, 1969), who accompanied Erle Stanley Gardner on his famous helicopter cave search. Meighan reported all their finds as in "the Sierra de San Borjas"(sic). Nevertheless, there is a clear geographic (as well as usage) distinction between the Sierras of San Borja and San Francisco, as the accompanying map suggests. None of the published accounts of large naturalistic paintings places them in the actual Sierra de San Borja.

Antonio Peralta, a rancher who lived far to the north, at San Agustín (near Mission San Fernando), but was reared at Calmalli, told me he had seen large paintings of men and animals north of there. Manuel Flores, a member of a large family of vaqueros working as tenant ranchers in the same sierra, told me of some such works, and gave me a couple of specific sites. Other reports of a vaguer character accumulated, and finally I had time to make a preliminary survey.

On April 1, 1974, I left the San Ignacio area on muleback, in the company of Enrique Hambleton, a Mexican photographer and close friend. 
Our arrieros (mule handlers) and animals were the same I had employed in six previous month-or-more field surveys in regions as distant as 150 kilometers south of San Ignacio. We rode north, checking reported sites all along the way. As far north as Santa Gertrudis, the pattern of painted works was invariably identical to that which I have learned to associate with the Sierra de San Francisco, the heart of the Great Mural region.

In the El Barril area, especially near Rancho Progreso, we visited four sites which were entirely different. All consisted of small paintings (under $24 "$ ) in maroon-red on granite rocks. Subject matter was still men and animals, but styles were quite discernibly different from works in the mountains to the south.

We rode north to Rancho La Bocana at the mouth of the great arroyo of San Pedro. There we acquired the services of Ignacio "Galo" Murillo, the resident rancher. Sr. Murillo took us up the arroyo, over the mountains through San Gregorio to San Borja, and eventually to San Regis. Only two hours' ride north of La Bocana, we made our first find, and it was independent of local knowledge.

We had stopped at an abandoned mining camp, hard by the ruins of the historic ranch of Arroyo San Pedro. The hour was not late, but the water there was to be our last for a long distance, so we made camp in order to water the animals in the morning. The rock of the arroyo was a weathered gray metamorphic, shot with quartz veins, and bearing much water. Over to the west, however, up a cañada, we could see hills of huge granite boulders, apparently veritable rock piles. Enrique determined to investigate, and walked the rough half-mile that intervened. I followed him a short way to a vantage point, and watched with binoculars. After a long scramble, Enrique stopped in front of a five-meter rock face, examined it, and turned toward me, giving the familiar both-arms-aloft signal which we use to denote human figures.

In that cañada, Enrique had found a site which yielded, in a run of only a hundred meters, at least five Great Mural figures, and a number of smaller ones. There were three deer at about $1^{1} / 2 \times$ life size, and two men at around $3 / 4$ scale. All were painted on granite rock in shades of red, from rust to maroon. I offered Enrique my heartiest congratulations, because he had established concretely the existence of large naturalistic paintings substantially north of the 28 th parallel.

Our entire trip consumed 31 days. During its course we were to locate other such works as far north as the arroyo of San Regis (at 28 35' N.Lat.) on the opposite (Pacific) drainage. All told, we identified seven Great Mural sites spread over the area shown on the map (Figure 1). 


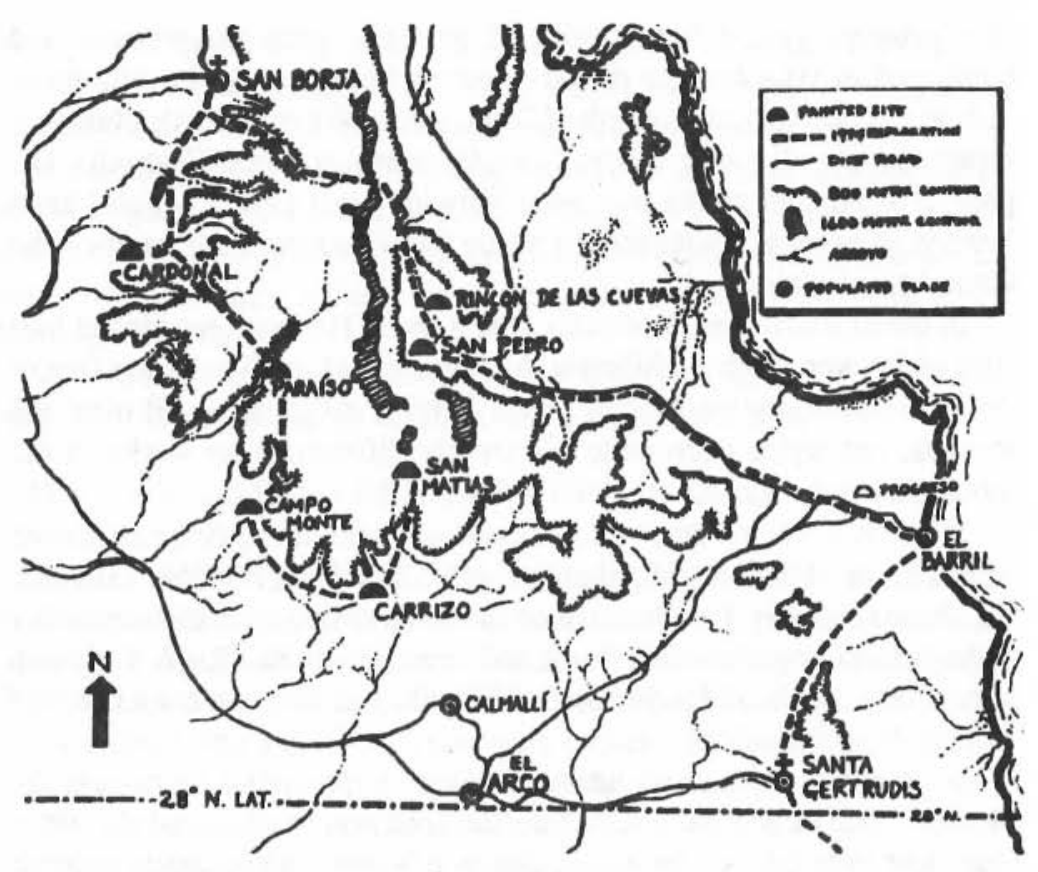

Figure 1. Map of the Red-on-Granite Region of the Sierra de San Borja.

As a postscript to our Red-on-Granite experiences, we explored further north. In doing so, we believe that we established the general location of an interface between two markedly different rock painting cultures. Only a little over 12 kilometers north of the village of San Borja, we visited an elaborately-painted site in a place locally known as Las Tinajitas, in Arroyo Grande. The works of art here are entirely of the small abstract polychrome type frequently reported between Bahía de los Ángeles and Cataviña. Ing. Emesto Raúl Lopez (1972:12) describes the site in Arroyo Grande, which he calls "San Borja". The same general sort of art occurs a few kilometers to the southwest at Lopez's "La Angostura" site, and, a few kilometers north, in Arroyo Montevideo at the site called "Volcancito" by López, and "Eagle Cliffs" by Anita Alvarez de Williams (1973:37).

All of these San Borja area sites seem to derive from a common culture, and relate to similar sites northward. The conclusion, then, is that the 
Red-on-Granite culture was their southern neighbor. It also seems indicated that the Red-on- Granite group had much stronger cultural affinities with the other Great Muralists to the south than with the abstract painters to the north. Such tentative conclusions are based on the paintings alone, and are not, to my knowledge, supported by other sorts of evidence.

\section{SUMMARY OF OBSERVATIONS}

Although space does not permit a thorough report here on these Sierra de San Borja sites, some usefull generalizations may be made about the Great Murals from this new area.

1. The paintings are in shades of red.

2. The works are executed on granitic rock, either in the form of large free-standing boulders, or weathered blocks of material in situ. (The badly-damaged Rincón de las Cuevas site is the only exception to 1 and 2 above. It is in a cave of agglomerated light volcanic materials, and displays polychrome work resembling some examples in the Santa Gertrudis region).

3. While large, the painted figures are smaller on the average than those in other Great Mural areas. Human figures, especially, tend to be around life-size or less, although three at Campo Monte are somewhat larger than life.

4. Subject matter in general is limited to deer, borrego (sheep), humans, and perhaps rabbits. A notable exception is a single rock face at Campo Monte displaying turtles and manta (or bat) rays.

5. Small paintings are found at or near several of these sites. (San Pedro, Campo Monte, San Matias, and Rancho Carrizo). In general, these appear to be later, but similar in paint and style. At all but Campo Monte, they are located on separate rocks, and lower than the Great Mural figures.

6. The style of the paintings at all sites (except, of course, the very aberrant Rincon de las Cuevas) is homogeneous and discernibly different from works elsewhere in the Great Mural area. Wholly apart from the similarity of their paint and rock surfaces (smooth granite), the works compel one to think of a regional "school". The differences are subtle enough, however, to require more space than we have here for proper elucidation. Perhaps only in the human figures can it be reduced to a few words:

Elsewhere in the Great Mural region, man has rather natural proportions, and invariably has upraised arms. In the Red-on- Granite realm of the Sierra de San Borja, man is represented less realistically: a stiff figure, with long torso and short limbs; the arms occasionally thrust down and out, instead of up and out. 


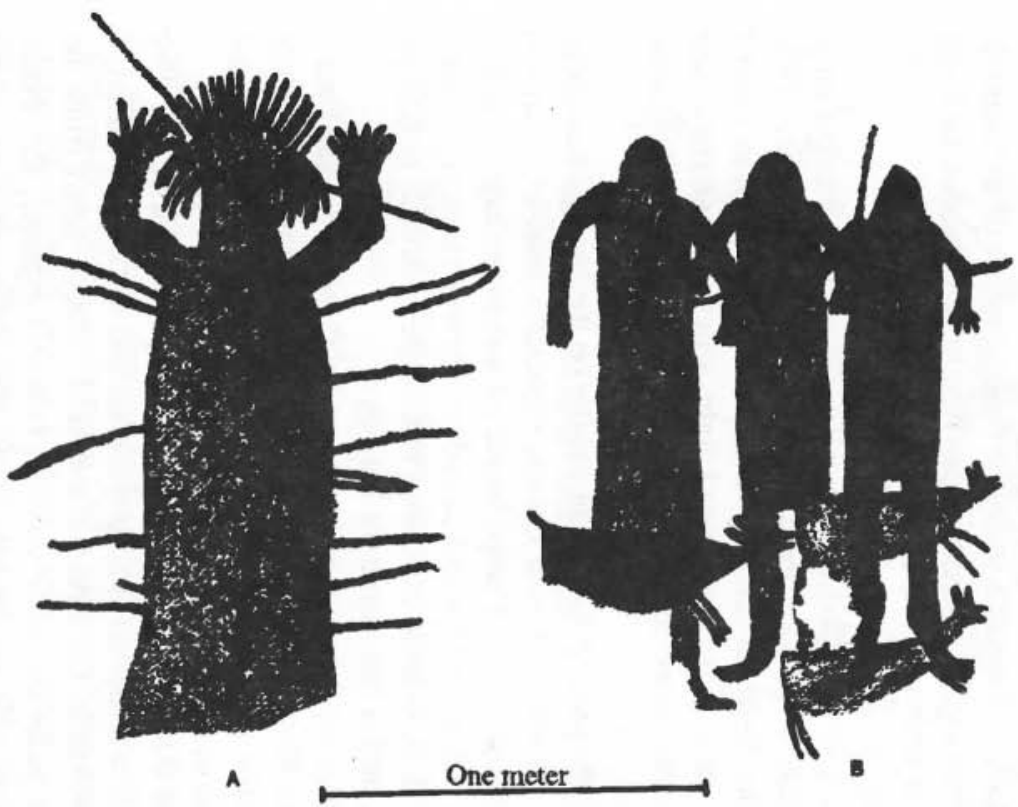

Figure 2. A. Human figure from San Matías (lower portion lost due to fallen rock fragment and water damage). B. Three human figures involved in overpainting with three deer (some damage lower center and left). From Campo Monte.

Ilustration by Joanne Crosby. 


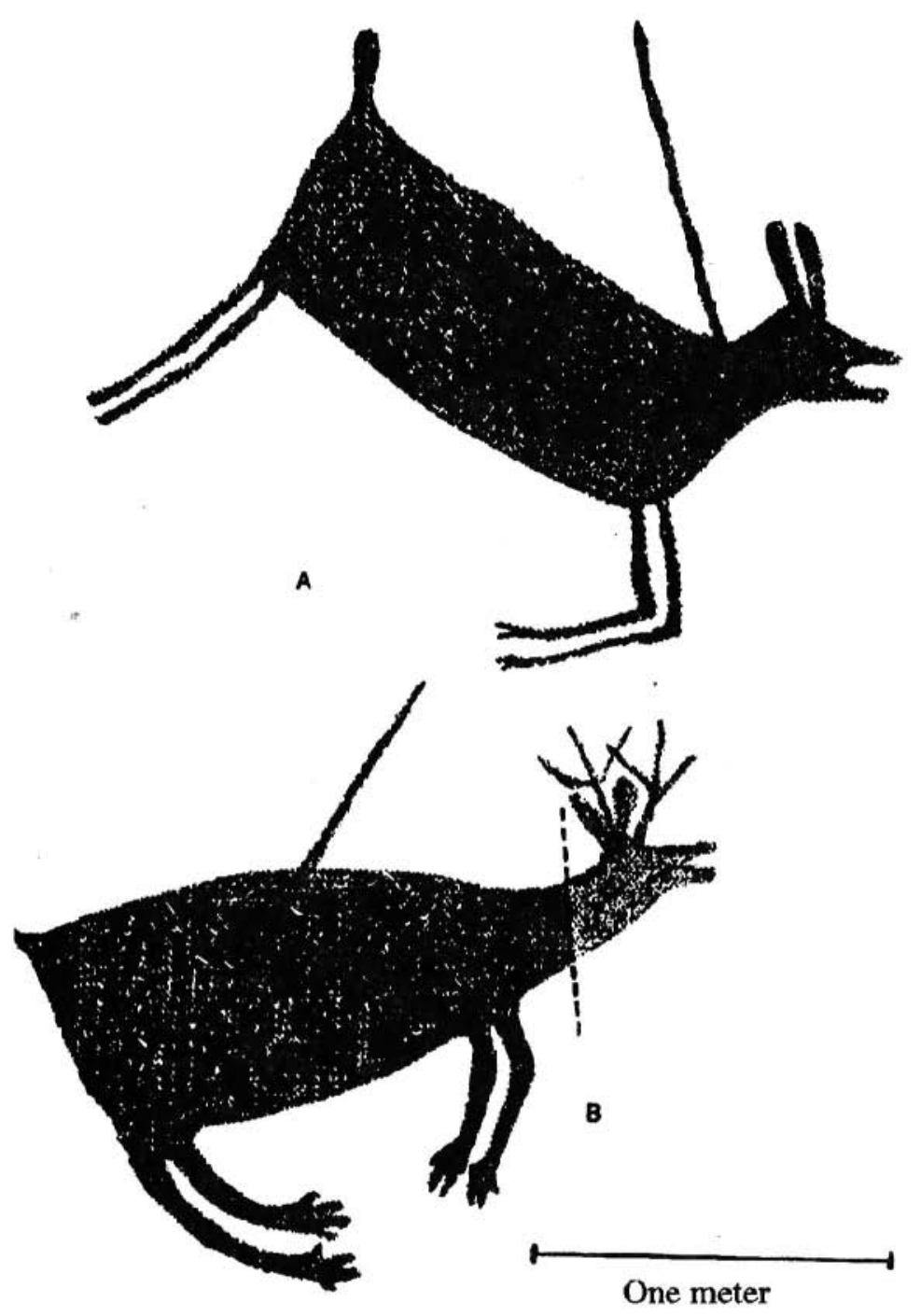

Figure 3. A. Deer from San Pedro (slight restoration of hindquarters in this facsimile).

B. Deer from El Paraíso (heavy restoration of head; other parts in excellent condition).

Ilustration by Joanne Crosby. 
7. The condition of all the Red-on-Granite works is remarkably similar. The paint has adhered unusually well to the granite; the hard, but finely-checked surface provides an excellent basis for an enduring mechanical bond. Offsetting this positive survival factor is the element of exposure. Most of these Red-on-Granite works are on the vertical faces of rounded boulders. Such faces are washed by every rain of any consequence, even if the paintings are on the rolled-under surfaces at the bases of the boulders. This situation contrasts strongly with most of the surviving Great Murals to the south, which are in rock shelters well protected from rain. The result of this exposure on the Sierra de San Borja is a rather uniform fading, coupled with occasional vertical streaks of greater damage, attributable to specific flows of water. Nevertheless it is important to reemphasize that there is a striking sameness to the condition of all the Red-on-Granite sites so far discovered. This, taken with their stylistic homogeneity, leads to a preliminary opinion that they were created by the members of a single cultural group during a relatively brief period of time. The only important instances of over-painting found in this style area, are at Campo Monte, and it seems significant that Campo Monte is by far the most variable site in other respects as well.

Further observations and conclusions would seem properly to await the gathering of significantiy greater amounts of data at additional sites.

The Sierra de San Borja is very lightly populated, particularly in its central and eastern reaches. For this reason it was unusually difficult to get local information, and our time probably produced a disproportionately low return, compared to similar surveys in the sierra to the south. For this reason, I estimate that many other sites, - dozens at least- exist, and will eventually be discovered. I also believe that these discoveries will be difficult, because the terrain is vast, rough, and poorly watered, factors which complement the lack of information in a most negative way. 


\section{REFERENCBS}

CLAVIJERO, Francisco Javier. 1937. The History of (Lower) California, translated by Sara E. Lake and A.A. Gray. Stanford University Press, Stanford.

GRANT, Campbell. 1974. Rock Art of Baja California. Baja California Travels Series , No.33. Dawson's Book Shop, Los Ángeles.

LOPEZ, Ernesto Raúl. 1972. "New Discoveries of Cave Paintings in Baja Califomia", translated by Aileen McKinney from Calafia, Vol.1, No.2. Pacific Coast Archaeological Society Quarterly, Vol.8, No.1, pp.10-14. Costa Mesa.

MEIGHAN, Clement W. 1966. "Prehistoric Rock Painting in Baja Califomia". American Antiquity, Vol.31, No.3. pp. 372-392. Salt Lake City.

- 1969. Indian Art and Fistory, the Testimony of Prehistoric Rock Paintings in Baja California. Baja California . California Travels Series, No.13. Dawson's Book Shop, Los Ángeles.

ALVAREZ de Williams, Anita. 1973. "Five Rock Art Sites in Baja California". Pacific Coast Archaeological Society Quarterly, Vol.9, No.4, pp. 37-46. Costa Mesa. 